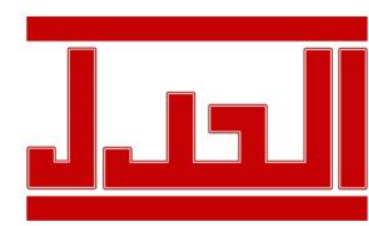

ISSN: $1979-4940$

E-ISSN : $2477-0124$
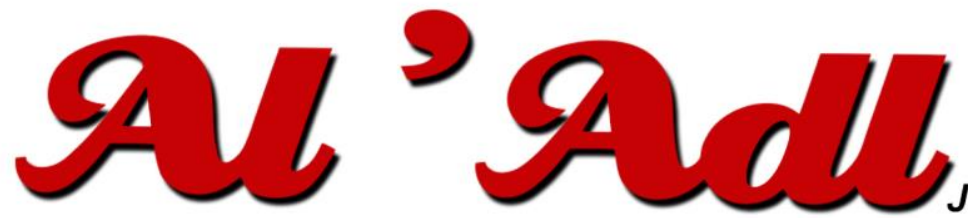

Jurnal Hukum

Editorial Office: Faculty of Law, Islamic University Of Kalimantan,

Jalan Adhyaksa No. 2 Kayutangi Banjarmasin, Kalimantan Selatan, Indonesia (70123)

Email: al_adl@uniska-bjm.ac.id

Web: http://ojs.uniska-bjm.ac.id

\section{KONSEP KEADILAN DALAM MEDIASI PADA LEMBAGA ALTERNATIF PENYELESAIAN SENGKETA PERBANKAN INDONESIA (LAPSPI)}

\author{
Nahdhah \\ Fakultas Hukum Unisversitas Islam Kalimantan Muhammad Arsyad Al Banjari \\ Jalan Adhyaksa No. 2 Kayutangi, Banjarmasin Kalimantan Selatan, Indonesia \\ Email: nahdhah.fhuniska@gmail.com,
}
Submitted
: 23 Desember 2020
Revised
Accepted
Published
: 25 Desember 2020
: 30 Januari 2021

\begin{abstract}
Banking mediation is considered very important, because in addition to settlement through this route it is deemed more effective and more efficient for the disputing parties. The presence of the Indonesian Banking Dispute Resolution Alternative Institute (LAPSPI) is certainly very helpful in carrying out banking dispute resolution and is expected to resolve civil disputes between customers and banks. The purpose of this study was to determine the characteristics of the mediation carried out by the Indonesian Banking Dispute Resolution Alternative Institute (LAPSPI) and the concept of justice in mediation carried out by the Indonesian Banking Dispute Resolution Alternative Institute (LAPSPI). The research method used is normative legal research which is descriptive analysis. The results of the research are the characteristics of the mediation carried out by the Indonesian Banking Dispute Resolution Alternative Institute (LAPSPI), which is based on the Financial Services Authority Regulation Number 01 / POJK.07 / 2014 concerning LAPS in the Financial Services sector regulates the dispute settlement mechanism in the banking sector, which can be pursued in 2 stages., namely: Internal Dispute Resolution, namely dispute resolution through the Financial Services Institution (LJK) and External Dispute Resolution, namely dispute resolution through judicial institutions (litigation) or outside the court (nonlitigation). POJK No. 01 / POJK.07 / 2014 Alternative Dispute Resolution Institutions in Article 7 states that the principle of justice in Alternative Dispute Resolution Institutions has regulations in making decisions with the following provisions: The mediator actually acts as a facilitator in bringing together the disputing parties to obtain an agreement. The solution in this case can be explained that the disputing parties, namely between the bank and the customer are enforced equally, namely in the assessment of a treatment / action
\end{abstract}

Keywords: Justice, mediation, LAPSPI

Abstrak
Mediasi perbankan dinilai sangat penting, dikarenakan selain penyelesaian melalui jalur ini dirasa lebih efektif
dan lebih efisien bagi para pihak yang bersengketa, kehadiran Lembaga Alternatif Penyelesaian Sengketa
Perbankan Indonesia (LAPSPI) tentu dirasakan sangat membantu dalam melaksanakan penyelesaian sengketa
perbankan dan diharapkan dapat menyelesaikan sengketa perdata antara nasabah dan bank. Tujuan penelitian ini
adalah untuk mengetahui karakteristik mediasi yang dilakukan oleh Lembaga Alternatif Penyelesaian Sengketa


Perbankan Indonesia (LAPSPI) dan konsep keadilan dalam mediasi yang dilakukan oleh Lembaga Alternatif Penyelesaian Sengketa Perbankan Indonesia (LAPSPI). Metode penelitian yang digunakan adalah penelitian hukum normatif bersifat diskriptif analisis. Adapun hasil penelitian adalah mediasi yang dilakukan oleh Lembaga Alternatif Penyelesaian Sengketa Perbankan Indonesia (LAPSPI) yaitu berdasarkan Peraturan Otoritas Jasa Keuangan Nomor 01/POJK.07/2014 tentang LAPS di sektor jasa keuangan mengatur mekanisme penyelesaian sengketa di bidang perbankan dapat ditempuh dengan 2 tahapan, yaitu : Internal Dispute Resolution yaitu penyelesaian sengketa melalui Lembaga Jasa Keuangan (LJK) dan Eksternal Dispute Resolution yaitu penyelesaian sengketa melalui lembaga peradilan (litigasi) atau diluar pengadilan (non litigasi) dan pada POJK No. 01/POJK.07/2014 Lembaga Alternatif Penyelesaian Sengketa pada Pasal 7 menyebutkan prinsip keadilan pada Lembaga Alternatif Penyelesaian Sengketa memiliki peraturan dalam pengambilan putusan dengan ketentuan sebagai berikut: Mediator benar-benar bertindak sebagai fasilitator dalam rangka mempertemukan para pihak yang bersengketa untuk memperoleh kesepakatan. Penyelesaian dalam hal ini dapat dijelaskan bahwa pihak yang bersengketa yaitu antara bank dan nasabah diberlakukan secara sama yaitu pada penilaian terhadap suatu perlakuan/tindakan

Kata Kunci : Keadilan, mediasi, LAPSPI

\section{PENDAHULUAN}

Lembaga keuangan, khususnya perbankan memiliki peran yang sangat penting terhadap pergerakan roda perekonomian Indonesia. Sebagaimana tujuannya dalam Pasal 4 Undang-Undang Perbankan" yang menyebutkan bahwa "Perbankan Indonesia bertujuan menunjang pelaksanaan pembangunan nasional dalam rangka meningkatkan pemerataan, pertumbuhan ekonomi dan stabilitas nasional ke arah peningkatan kesejahteraan rakyat banyak."Pembangunan nasional ini merupakan upaya pembangunan yang berkesinambungan dalam rangka mewujudkan masyarakat yang adil dan makmur berdasarkan Pancasila dan Undang-Undang Dasar $1945 .^{2}$

Lembaga Keuangan Bank merupakan lembaga yang kegiatannya menghimpun dana langsung dari masyarakat dalam bentuk simpanan, misalnya deposito, giro, tabungan. Selain menghimpun juga memberikan jasa pelayanan keuangan kepada masyarakat. Lembaga ini biasanya menawarkan jasa sama seperti bank yang memudahkan dalam transaksi keuangan.

Sementara itu, terdapat dua jenis peranan perbankan, yaitu peranan dalam negeri dan peranan luar negeri. Peranan dalam negeri artinya adalah bank mempunyai peranan untuk memenuhi kebutuhan-kebutuhan ekonomi dalam negeri seperti kegiatan administrasi keuangan, penampungan uang, penggunaan uang, penukaran dan perdagangan uang, pengawasan uang, perkreditan, dan pengiriman uang, sedang peranan perbankan untuk luar negeri meliputi hal-hal yang berkaitan dengan lalu lintas devisa, hubungan perdagangan, dan

\footnotetext{
${ }^{1}$ Undang-Undang Republik Indonesia Nomor 7 Tahun 1992 sebagaimana telah diubah dengan UndangUndang Nomor 10 Tahun 1998 Tentang Perubahan Undang-Undang Nomor 7 Tahun 1992 Tentang Perbankan. Lembaran Negara Republik Indonesia Tahun 1998 Nomor 182. Tambahan Lembaran Negara Republik Indonesia Nomor 3790.Selanjutnya disebut UU Perbankan.

${ }^{2}$ Ibid., Penjelasan Umum Paragraf 1.
} 
hubungan moneter antar negara. Tanpa adanya industri perbankan tidak akan terjadi akumulasi uang dari masyarakat untuk disalurkan dalam bentuk kredit pada berbagai industri, hal ini akan merusak sendi-sendi perekonomian dan pembangunan nasional

Interaksi yang intens antara Bank dan nasabah dapat menimbulkan perselisihan dan sengketa yang pada dasarnya perselisihan dan sengketa di berbagai kegiatan bisnis adalah sesuatu yang tidak diharapkan karena akan menimbulkan kerugian pada pihak yang bersengketa. Namun terkadang sengketa tidak dapat dihindari karena adanya kesalahpahaman, pelanggaran undang-undang, ingkar janji, kepentingan yang berlawanan dan atau terjadi kerugian pada salah satu pihak. Menurut Rachmadi Usman, sengketa adalah pertentangan antara dua pihak atau lebih yang berawal dari persepsi yang berbeda tentang suatu kepentingan atau hak milik yang dapat menimbulkan akibat hukum bagi keduanya. ${ }^{3}$

Salah satu penyebab terjadinya perselisihan antara bank dan nasabah dalam interaksinya karena terjadi friksi yang apabila tidak segera diselesaikan dengan baik akan berubah menjadi sengketa. Timbulnya friksi tersebut terutama disebabkan oleh empat hal yaitu:

1. Informasi yang kurang memadai mengenai karakteristik produk atau jasa yang ditawarkan bank;

2. Pemahaman nasabah terhadap aktivitas dan produk serta jasa perbankan yang masih kurang;

3. Ketimpangan hubungan antara nasabah dengan bank, khususnya bagi nasabah peminjam dana;

4. Tidak adanya saluran memadai untuk memfasilitasi penyelesaian friksi yang terjadi antara nasabah dengan bank. ${ }^{4}$

Melihat dari empat hal tersebut maka bisa dilihat bahwa sangat mudahnya terjadi perselisihan atau sengketa antara nasabah dengan bank. Pentingnya perlindungan hukum bagi konsumen disebabkan posisi tawar konsumen yang lemah. Perlindungan hukum terhadap konsumen mensyaratkan adanya pemihakan kepada posisi tawar yang lemah (konsumen). ${ }^{5}$

Perlindungan nasabah merupakan tantangan perbankan yang berpengaruh secara langsung terhadap sebagian besar masyarakat. Oleh karena itu menjadi tantangan yang sangat

\footnotetext{
${ }^{3}$ Rachmadi Usman, (2013), Pilihan Penyelesaian Sengketa di Luar Pengadilan, Bandung: Citra Aditya Bakti, hlm. 3.

${ }^{4}$ Andika Persada Putera, (2013), "Penyelesaian Sengketa Perbankan Dengan Mediasi", Jurnal Yuridika, Vol. 28, No. 1, hlm. 16. https://e-journal.unair.ac.id/YDK/article/view/5713/3609

${ }^{5}$ Sudaryatmo, (1999), Hukum dan Advokasi Konsumen, Bandung: Citra Aditya Bakti, hlm. 90.
} 
besar bagi perbankan dan Bank Indonesia untuk menciptakan standar yang jelas dalam memberikan perlindungan kepada nasabah.

Perlindungan hukum bagi konsumen dalam bentuk perlindungan hukum yang diberikan oleh negara. Tumbuhnya kesadaran negara untuk memberikan perlindungan hukum bagi konsumen yang berada dalam posisi tawar yang lemah, dimulai dengan memikirkan berbagai kebijakan. ${ }^{6}$ Berdasarkan Undang-Undang Nomor 21 Tahun 2011 Tentang Otoritas Jasa Keuangan telah dibentuk lembaga independen dan bebas dari campur tangan pihak lain, yang mempunyai fungsi, tugas atau wewenang pengaturan, pengawasan, pemeriksaan dan penyidikan di sektor keuangan. Berdasarkn Pasal 4 Undang-Undang No.21 Tahun 2011 tentang Otoritas Jasa Keuangan. Otoritas Jasa Keuangan dibentuk dengan tujuan agar keseluruhan kegiatan di dalam sektor jasa keuangan:

a. terselenggara secara teratur, adil, transparan, dan akuntabel;

b. mampu mewujudkan sistem keuangan yang tumbuh secara berkelanjutan dan stabil; dan

c. mampu melindungi kepentingan Konsumen dan masyarakat.

Sebagaimana yang diamanatkan dalam POJK Nomor 1/POJK.07/2013 tanggal 26 juli 2013 tentang perlindungan konsumen Sektor Jasa Keuangan dan POJK No. 01/POJK.07/2014 tentang Lembaga Alternatif Penyelesaian Sengketa (LAPS) di sektor Jasa keuangan, dalam rangka perlindungan dan pemberdayaan nasabah diwujudkan dengan keberadaan infrastrutur untuk menangani dan menyelesaikan berbagai keluhan dan pengaduan nasabah kepada Bank.

Dalam konteks penyelesaian suatu sengketa perbankan, peranan lembaga mediasi sangatlah penting dalam upaya mencapai kesetaraan antara para pihak yang berada dalam konflik sehingga dapat menyelesaikan secara internal. Dimana salah satu upaya melalui mekanisme mediasi. ${ }^{7}$ Dewasa ini hampir semua negara mengembangkan berbagai jalan terobosan alternatif, karena kelemahan penyelesaian sengketa melalui ajudikasi yang

${ }^{6}$ Paulee A. Coughlin, (1994), "The Movement of Consumer Protection in the European Community: A Vital Link in the Establishment of Free Trade and a Paradigm for North America, International and Competition Law Review, No. 143, hlm. 162. Dikutip dari Abdul Halim Barkatullah, (2007), "Urgensi Perlindungan Hak-hak Konsumen Dalam Transaksi Di E-Commerce", Jurnal Hukum, Vol. 14, No. 2, April, hlm. 247 - 270 , https://media.neliti.com/media/publications/110734-ID-urgensi-perlindungan-hak-hak-konsumen-da.pdf

${ }^{7}$ Inosentius Samsul, (2009), Pengembangan Model Penyelesaian Sengketa Perbankan dalam Perpekstif Perlindungan Konsumen, Buletin Hukum Perbankan dan Kebanksentralan, Direktur Hukum Bank Indonesia, Jakarta, hlm.27-28 
mengakibatkan terkurasnya sumber daya, dana, waktu, pikiran dan tenaga, dan mulai mengedepankan pola-pola penyelesaian sengketa di luar pengadilan. ${ }^{8}$

Dalam dunia perbankan di Indonesia, proses mediasi sebagai salah satu bentuk penyelesaian sengketa alternatif yang merupakan kelanjutan dari pengaduan nasabah apabila nasabah merasa tidak puas atas penanganan dan penyelesaian yang diberikan bank. Mediasi perbankan dinilai sangat penting, dikarenakan selain penyelesaian melalui jalur ini dirasa lebih efektif dan lebih efisien bagi para pihak yang bersengketa. Kehadiran Lembaga Alternatif Penyelesaian Sengekta Perbankan Indonesia (LAPSPI) tentu dirasakan sangat membantu dalam melaksanakan penyelesaian sengketa perbankan dan diharapkan dapat menyelesaikan sengketa perdata antara nasabah dan bank jika terjadi sengketa.

Pada saat ini LAPSPI menjadi pilihan yang bagus dalam menyelesaikan sengketa jika dilihat dari kurva yang selalu mengalami peningkatan dalam menyelesaikan sengketa. Keberadaan LAPSPI dinilai lebih meyakinkan dibanding lembaga penyelesaian sengketa lain karena LAPSPI spesifik hanya melayani sengketa di bidang perbankan yangmana kredibilitasnya tidak meragukan akan tetapi hal ini dapat mejadi menarik dimana ketika LAPSPI menjadi pilihan terbaik dalam menyelesaikan sengketa namun apakah proses mediasi yang dijalankan sudah memenuhi aspek keadilan sebagaimana yang diharapkan oleh kedua belah pihak yang bersengketa. Oleh karena itu menarik untuk dilakukan penelitian mengenai Konsep Keadilan dalam Mediasi pada Lembaga Alternatif Penyelesaian Sengketa Perbankan Indonesia (LAPSPI)

\section{RUMUSAN MASALAH}

Berdasarkan latar belakang masalah yang telah dijelaskan di atas maka rumusan masalah dalam penelitian ini adalah bagaimana konsep keadilan dalam mediasi yang dilakukan oleh Lembaga Alternatif Penyelesaian Sengketa Perbankan Indonesia (LAPSPI)?

\section{TUJUAN PENELITIAN}

Tujuan penelitian pada penelitian ini adalah untuk mengetahui konsep keadilan dalam mediasi yang dilakukan oleh Lembaga Alternatif Penyelesaian Sengketa Perbankan Indonesia (LAPSPI)

${ }^{8}$ Susanti Adi Nugroho, (2008), Proses Penyelesaian Sengketa Konsumen Ditinjau dari Hukum Acara serta Kendala Implementasinya, Jakarta: Kencana, hlm.13 


\section{METODE PENELITIAN}

Jenis Penelitian yang digunakan dalam tulisan ini termasuk ke dalam penelitian hukum normatif. Dalam penelitian normartif adalah penelitian yang ingin menemukan kebenaran hukum yang bersifat dogmatis, membutuhkan data sekunder yang bersumber dari hukum positif (das solen). ${ }^{9}$ Penelitian hukum normatif memandang hukum sebagai suatu norma/peraturan tertulis yang ditetapkan oleh lembaga yang mempunyai otoritas. Data yang digunakan dalam penelitian ini adalah data sekunder. Seluruh data yang terkumpul dianalisis dengan menggunakan metode kualitatif. Hasil penelitian ini disajikan dalam suatu laporan yang bersifat diskriptif analisis. Bersifat deskriptif karena dari penelitian ini diharapkan dapat memberikan gambaran secara menyeluruh dan sistematis mengenai asas-asas hukum, kaidahkaidah hukum, doktrin dan peraturan perundang-undangan yang berkaitan dengan penelitian ini.

\section{TINJAUAN PUSTAKA}

\section{Mediasi Perbankan}

Mediasi perbankan merupakan alternatif penyelesaian sengketa yang sangat diperlukan, karena sering terjadinya perselisihan antara nasabah dan bank yang menyebabkan terjadinya sengketa antara nasabah dan bank. Hal ini dapat dilihat pada tingginya kebutuhan nasabah terhadap adanya mekanisme penanganan dan penyelesaian pengaduan tercemin dari tingginya jumlah pengaduan yang diterima oleh bank.

Secara etimologi mediasi berasalah dari Bahasa latin yaitu "mediare" yang berarti berada di tengah. Makna ini menunjuk pada peran pihak ketiga sebagai mediator dalam menjalankan tugasnya menegahi dan menyelesaikan sengketa para pihak, juga bermakna pada posisi netral dan tidak memihak dalam menyelesaikan sengketa. ${ }^{10}$ 4Black's Law Dictionary mendefinisikan mediasi : "mediation is private, informal dispute resolution process in which a neutral third person, the mediator helps disputing partie to reach an agreement". "... the mediator has no power to impose a decision on the parties". Menekankan penyelesaian perselisihan yang melibatkan pihak ketiga sebagai penengah untuk mencapai kesepakatan bersama pihak yang bersengketa.

9 Elisabeth Nurhaini Butarbutar, (2018), Metode Penelitian Hukum (Langkah-Langkah Untuk Menemukan Kebenaran Dalam Lmu Hukum), Bandung: Refika Aditama, hlm. 71

10 Syahrizal Abbas, (2009), Mediasi Dalam Perspektif Hukum Syariah, Hukum Adat, Dan Hukum Nasional, Jakarta: Kencana Perasada Media Group, Dikutip dari Nahdhah, Ningrum Ambarsari, (2019), "Mediasi Perbankan Melalui Lembaga Alternatif Penyelesaian Sengketa Perbankan Indonesia (LAPSPI)", Jurnal Banua Law Review, Vol. 2. No. 1 https://balrev.ulm.ac.id/index.php/balrev/article/view/6/pdf 
"Mediasi" adalah proses negosiasi penyelesaian masalah (sengketa) dimana suatu pihak luar, tidak memihak, netral, tidak bekerja dengan para pihak yang besengketa, membantu mereka (yang bersengketa) mencapai suatu kesepakatan hasil negosiasi yang memuaskan.

Mediation is a process in which two or more people involved in a dispute come together, to try to work out a solution to their problem with the help of a neutral third person, called the "Mediator".

"Mediasi" adalah proses penyelesaian sengketa yang melibatkan mediator untuk membantu para pihak yang bersengketa guna mencapai penyelesaian dalam bentuk kesepakatan sukarela terhadap sebagian atau seluruh permasalahan yang disengketakan.

Dari perumusan-perumusan diatas dapat disimpulkan bahwa :

1. Tidak sebagaimana halnya seorang hakim atau arbiter, seorang mediator tidak dalam posisi (tidak mempunyai kewenangan) untuk memutus sengketa para pihak.

2. Tugas dan kewenangan mediator hanya membantu dan memfasilitasi pihakpihak yang bersengketa dapat mencapai suatu keadaan untuk dapat mengadakan kesepakatan tentang hal-hal yang disengketakan. "The assumption.......is that third party will be able to alter the power and social dynamics of the conflict relationship by influencing the beliefs and behaviors of individual parties, by providing knowledge and information, or by using a more effective negotiation process and thereby helping the participants to settle contested issues"

3. Mediasi adalah Non-Coercive. Ini berarti bahwa tidak ada suatu sengketa (yang diselesaikan melalaui jalur mediasi) akan dapat diselesaikan, kecuali hal tersebut disepakati / disetujui bersama oleh pihak-pihak yang bersengketa. ${ }^{11}$

Dapat dikatakan bahwa Mediasi dapat diterapkan dan dipergunakan untuk mempergunakan sebagai cara penyelesaian sengketa diluar jalur pengadilan (“Out-of court Settlement") untuk sengketa perdata yang timbul diantara para pihak, dan bukan perkara pidana. Jenis sengketa yang dapat diselesaikan melalui Mediasi LAPSPI harus memenuhi semua kriteria tersebut di bawah ini:

${ }^{11}$ Felix Oentoeng Soebagjo, Mediasi Sebagai Alternatif Penyelesaian Sengketa Dibidang Perbankan, Bahan Diskusi Terbatas "Pelaksanaan Mediasi Perbankan oleh Bank Indonesia Dan Pembentukan Lembaga Independen Mediasi Perbankan”. Kerjasama Magister Hukum Bisnis Dan Kenegaraan, Universitas Gadjah Mada, Yogyakarta, Dan Bank Indonesia. Yogyakarta, 21 Maret 2007, dapat diakses secara online pada http://bapmi.org/pdf/DiskusiTerbatasPelaksanaanMediasi_FelixSoebagjo.pdf 
1. Merupakan sengketa perdata di bidang Perbankan atau berkaitan dengan bidang Perbankan;

2. Sengketa mengenai hak yang menurut hukum dan peraturan perundang-undangan dikuasai sepenuhnya oleh Pihak yang bersengketa;

3. Sengketa yang menurut peraturan perundang-undangan dapat diadakan perdamaian;

4. Sengketa yang telah menempuh upaya musyawarah tetapi Para Pihak tidak berhasil mencapai perdamaian; dan

5. Antara Pemohon dan Termohon telah terikat dengan Perjanjian Mediasi

Tujuan Mediasi terbagi menjadi 2 yaitu:

\section{Utama}

1. Membantu mencarikan jalan keluar/alternative penyelesaian atas sengketa yang timbul diantara para pihak yang disepakati dan dapat diterima oleh para pihak yang bersengketa.

2. Dengan demikian proses negosiasi adalah proses yang forward looking dan bukan backward looking. Yang hendak dicapai bukanlah mencari kebenaran dan/atau dasar hukum yang diterapkan namun lebih kepada penyelesaian masalah. "The goal is not truth finding or law imposing, but problem solving"

\section{Tambahan}

1. Melalui proses mediasi diharapkan dapat dicapai terjalinnya komunikasi yang lebih baik diantara para pihak yang bersengketa.

2. Menjadikan para pihak yang bersengketa dapat mendengar, memahami alasan/ penjelasan/ aurgumentasi yang menjadi dasar/pertimbangan pihak yang lain.

3. Dengan adanya pertemuan tatap muka, diharapkan dapat mengurangi rasa marah/bermusuhan antara pihak yang satu dengan yang lain.

4. Memahami kekurangan/kelebihan/kekuatan masing-masing, dan hal ini diharapkan dapat mendekatkan cara pandang dari pihak-pihak yang bersengketa, menuju suatu kompromi yang dapat diterima para pihak $^{12}$

Dapat dikatakan bahwa Mediasi dapat diterapkan dan dipergunakan untuk mempergunakan sebagai cara penyelesaian sengketa diluar jalur pengadilan ("Out-of court Settlement") untuk sengketa perdata yang timbul diantara para pihak, dan bukan perkara

\footnotetext{
${ }^{12}$ Ibid., hlm. 3
} 
pidana. Dengan demikian, setiap sengketa perdata dibidang perbankan dapat diajukan dan untuk diselesaikan melalui Lembaga Medasi Perbankan.

Dalam praktiknya, sebagai bagian dari proses mediasi, mediator dapat berbicara langsung secara rahasia dengan masing-masing pihak tanpa dihadiri oleh pihak lain. Hal ini menunjukkan bahwa mediasi masih merupakan bagian yang berantai dengan musyawarah atau negosiasi sebelumnya. Hanya saja pada mediasi melibatkan pihak ketiga sebagai mediator, dan hal tersebut tidak ada pada musyawarah atau negosiasi. Akhir dari sebuah proses mediasi bisa salah satu dari dua kemungkinan, pertama; apabila tercapai suatu kesepakatan, para pihak akan menandatangani sebuah dokumen penyelesaian yang selanjutnya akan diproses ke dalam bentuk perjanjian yang mengikat. Atau kemungkinan kedua; jika kesepakatan tidak tercapai, para pihak mengakhiri mediasi dengan mengajukan pengunduran diri dari proses mediasi. Pengunduran diri ini diajukan secara tertulis kepada mediator dan para pihak lainnya. ${ }^{13}$

\section{Lembaga Alternatif Penyelesaian Sengketa Perbankan Indonesia (LAPSPI)}

Lembaga Alternatif Penyelesaian Sengketa Perbankan Indonesia (LAPSPI), alamat Griya Perbanas Lt.1 Jl. Perbanas, Karet Kuningan Setiabudi, Jakarta bergerak pada sektor Perbankan dibentuk berdasarkan POJK No. 01/POJK.07/2014 tentang Lembaga Alternatif Penyelesaian Sengketa, hanya LAPS yang dimuat dalam daftar lembaga alternatif penyelesaian sengketa yang ditetapkan oleh OJK yang dapat menangani sengketa pada sektor jasa keuangan. Dalam hal sengketa perbankan, maka nasabah dan bank dapat menyselesaikannya di Lembaga Alternatif Penyelesaian Sengketa Perbankan Indonesia (LAPSPI)

Penyelesaian sengketa di luar pengadilan sebagaimana yang diamanatkan dalam Pasal 2 POJK Nomor 1/POJK.07/2014 tentang Lembaga Alternatif Penyelesaian Sengketa di Sektor Jasa Keuangan dilakukan melalui LAPSPI sebagai lembaga alternatif penyelesaian sengketa di sektor perbankan yang terdaftar dalam daftar LAPS yang ditetapkan OJK

Pendirian Lembaga Alternatif Penyelesaian Sengeta Perbankan Indonesia (LAPSPI) tidak terlepas dari kenyataan bahwa dalam penyelesaian pengaduan konsumen oleh lembaga perbankan seringkali tidak tercapai kesepakatan antara konsumen dengan lembaga perbankan.

\footnotetext{
${ }^{13}$ Gatot Soemartono, (2006), Arbitrase dan Mediasi di Indonesia, Jakarta: Gramedia, hlm. 132 dikutip dari Rika Delfa Yona, (2014), "Penyelesaian Sengketa Perbankan Syariah di Indonesia", Economic: Jurnal Ekonomi dan Hukum Islam, Vol. 4, No. 1. https://d1 wqtxts1 xzle7.cloudfront.net/40894987/961-2934-2-PB.pdf
} 
Untuk mengatasi hal tersebut diperlukan Lembaga Alternatif Penyelesaian Sengketa di luar pengadilan yang ditangani oleh orang-orang yang memahami dunia perbankan dan mampu menyelesaikan sengketa secara cepat, murah, adil, dan efisien.

Pendirian LAPSPI mempunyai maksud dan tujuan sebagai berikut:

1. Memenuhi kebutuhan masyarakat untuk tersedianya mekanisme penyelesaian sengketa di luar pengadilan dibidang jasa keuangan sektor Perbankan baik konvensional maupun syariah yang cepat, murah, adil dan efisien.

2. Mewujudkan koordinasi dan kerjasama di antara perkumpulan atau asosiasi di sektor Perbankan dalam penyelesaian sengketa dengan tetap memperhatikan karakteristik permasalahan dengan mengedepankan independensi dan kepatuhan pada peraturan perundang-undangan. ${ }^{14}$

\section{PEMBAHASAN}

\section{Mediasi pada Lembaga Alternatif Penyelesaian Sengketa Perbankan Indonesia} (LAPSPI)

Setiap terjadi sengketa, berbagai cara dapat digunakan untuk menyelesaikannya. Bahkan, saat ini marak adanya kecenderungan masyarakat untuk menggunakan kekerasan sebagai penyelesaian sengketa. Masyarakat memandang bahwa dengan melakukan kekerasan, sengketa yang terjadi akan dapat diselesaikan. Penyelesaian sengketa dengan cara kekerasan tidak akan pernah dapat diselesaikan karena masing-masing pihak akan berusaha untuk membalas kekalahan kepada pihak lainnya. Penyelesaian sengketa di luar pengadilan adalah penyelesaian sengketa perbankan melalui Lembaga Penyelesaian Sengketa Perbankan Indonesia (LAPSPI).

Berkaitan dengan hal tersebut, OJK telah mengeluarkan POJK No. 01/POJK.07/2014 tentang Lembaga Alternatif Penyelesaian Sengketa (LAPS) di Sektor Jasa Keuangan bertujuan untuk menciptakan sistem perlindungan konsumen yang andal, meningkatkan pemberdayaan konsumen, dan menumbuhkan kesadaran Lembaga Jasa Keuangan sehingga mampu meningkatkan kepercayaan masyarakat pada sektor jasa keuangan.

Beberapa pertimbangan mengapa memilih Mediasi LAPSPI untuk menyelesaikan sengketa:

${ }^{14}$ Yusuf Wahyu Wibowo, (2017), “Alternatif Penyelesaian Sengketa Perbankan Melalui Lembaga Alternatif Penyelesaian Perbankan Indonesia (LAPSPI)", Universitas Lampung. http://digilib.unila.ac.id/25789 /3/skripsi\%20tanpa\%20bab\%20pembahasan.pdf 
1. Mediator LAPSPI mampu membantu menyelesaikan permasalahan para pihak secara adil, cepat, murah dan efisien.

2. Mediator LAPSPI adalah para profesional di bidang industri perbankan yang memahami dengan baik dunia perbankan dan mempunyai keahlian mediasi serta telah mempunyai sertifikat mediator nasional.

Mediasi melalui LAPSPI dilakukan secara tertutup untuk umum sehingga unsur kerahasiaannya dapat terjaga. Sebagai lembaga alternatif penyelesaian sengketa, LAPSPI menjamin dan menjunjung tinggi integritas, kemandirian dan imparsialitas para mediator, ajudikator, arbiternya, sebagaimana yang diatur dalam kode etik LAPSPI.

Berdasarkan Peraturan Otoritas Jasa Keuangan Nomor 1/POJK.07/2014 tentang Lembaga Alternatif Penyelesaian Sengketa di Sektor Jasa Keuangan, LAPS memiliki prinsip sebagai berikut:

1. Prinsip aksesibilitas

Layanan penyelesaian sengketa mudah diakses oleh konsumen dan mencakup seluruh Indonesia.

2. Prinsip independensi

LAPS memiliki organ pengawas untuk menjaga dan memastikan independensi SDM

LAPS. Selain itu, LAPS juga memiliki sumber daya yang memadai sehingga tidak tergantung kepada Lembaga Jasa Keuangan tertentu.

3. Prinsip keadilan

Mediator di LAPS bertindak sebagai fasilitator dalam rangka mempertemukan kepentingan para pihak dalam memperoleh kesepakatan penyelesaian sengketa, sedangkan ajudikator dan arbiter wajib memberikan alasan tertulis dalam tiap putusannya. Jika ada penolakan permohonan penyelesaian sengketa dari konsumen dan Lembaga Jasa Keuangan, LAPS wajib memberikan alasan tertulis.

4. Prinsip efisiensi dan efektivitas

LAPS mengenakan biaya murah kepada konsumen dalam penyelesaian sengketa. Penyelesaian sengketa di LAPS dilakukan dengan cepat. Pelaksanaan putusan diawasi oleh LAPS. ${ }^{15}$

Penyelesaian sengketa melalui LAPSPI haruslah memenuhi kriteria persyaratan yaitu:

${ }^{15}$ OJK, Lembaga Alternatif Penyelesaian Sengketa LAPS, https://www.ojk.go.id/id/kanal/edukasi-danperlindungan-konsumen/Pages/Lembaga-Alternatif-Penyelesaian-Sengketa.aspx 
1. Merupakan sengketa perdata di bidang Perbankan dan/atau berkaitan dengan bidang Perbankan.

2. Sengketa mengenai hak yang menurut hukum dan peraturan perundangundangan dikuasai sepenuhnya oleh Pihak yang bersengketa.

3. Sengketa yang menurut peraturan perundang-undangan dapat diadakan perdamaian.

4. Sengketa yang telah menempuh upaya musyawarah tetapi Para Pihak tidak berhasil mencapai perdamaian, dan

5. Antara Para Pihak terikat dengan Perjanjian Mediasi. ${ }^{16}$

Peraturan Otoritas Jasa Keuangan Nomor 01/POJK.07/2014 tentang LAPS di sektor Jasa Keuangan mengatur mekanisme penyelesaian sengketa di bidang perbankan dapat ditempuh dengan 2 tahapan, yaitu :

1. Internal Dispute Resolution yaitu penyelesaian sengketa melalui Lembaga Jasa Keuangan (LJK)

Internal Dispute Resolution adalah penyelesaian pengaduan nasabah yang dilakukan oleh bank. POJK No.1/2013 mewajibkan setiap bank untuk memiliki unit yang dibentuk secara khusus di setiap kantor bank untuk menangani dan menyelesaikan pengaduan yang diajukan oleh konsumen tanpa dipungut bayaran. Penyelesaian sengketa perbankan oleh bank bertujuan untuk memaksa seluruh bank agar bersedia dan peduli dalam menyelesaikan seluruh sengketa yang terjadi dengan nasabah kecil, dengan maksud memberikan pelayanan sehingga dapat berpotensi meningkatkan reputasi pelayanan sebuah bank menjadi lebih baik.

Kewajiban tersebut berdasarkan Pasal 32 Ayat (1) yang menentukan "Pelaku Usaha Jasa Keuangan wajib memiliki dan melaksanakan mekanisme pelayanan dan penyelesaian pengaduan bagi konsumen". Pengaduan adalah penyampaian ungkapan ketidakpuasan konsumen yang disebabkan oleh adanya kerugian atau potensi kerugian finansial pada konsumen yang diduga terjadi karena kesalahan atau kelalaian Lembaga Jasa Keuangan dalam kegiatan penempatan dana oleh konsumen pada Lembaga Jasa Keuangan dan/atau pemanfaatan pelayanan dan/atau produk Lembaga Jasa Keuangan

2. Eksternal Dispute Resolution yaitu penyelesaian sengketa melalui lembaga peradilan (litigasi) atau diluar pengadilan (non litigasi)

\footnotetext{
${ }^{16}$ Ibid., hlm.4
} 
Litigasi adalah penyelesaian sengketa yang dilakukan melalui pengadilan. Penyelesaian sengketa melalui litigasi dapat dikatakan sebagai penyelesaian sengketa yang memaksa salah satu pihak untuk menyelesaikan sengketa dengan perantara pengadilan. Litigasi adalah proses penyelesaian sengketa di pengadilan, semua pihak yang bersengketa saling berhadapan satu sama lain untuk mempertahankan hak-haknya

Non litigasi adalah penyelesaian sengketa yang dilakukan berdasarkan kesepakatan para pihak dan prosedur penyelesaian atas suatu sengketa diserahkan sepenuhnya kepada para pihak yang bersengketa. Penyelesaian sengketa perbankan di luar pengadilan dapat dilakukan melalui berbagai cara, yaitu: mediasi, ajudikasi dan arbitrase

Pendaftaran Permohonan Mediasi Mediasi diselenggarakan berdasarkan permohonan yang diajukan oleh Para Pihak atau salah satu Pihak kepada LAPSPI. Permohonan diajukan secara tertulis kepada Ketua LAPSPI, dan dialamatkan ke Kantor LAPSPI.

Permohonan terdiri atas :

Surat permohonan Mediasi yang memuat

1. Nama lengkap dan tempat tinggal atau tempat kedudukan para pihak

2. Uraian singkat tentang sengketa

3. Isi tuntutan;

Lampiran-lampiran :

1. Fotocopy bukti pembayaran atas Biaya Pendaftaran

2. Fotocopy Perjanjian Mediasi

3. Akta-akta bukti yang diajukan berikut keterangannya

4. Fotocopy/salinan dokumen bukti-bukti pendukung

Mediasi. Menandatangani surat-surat undangan pertemuan kepada Para Pihak atas nama Mediator. Membantu Para Pihak dan Mediator menyiapkan format konsep Kesepakatan Perdamaian. Membantu Mediator dalam menyusun jadwal perundingan dan mengingatkan Mediator dan Para Pihak mengenai jangka waktu Mediasi. Menyiapkan konsep laporan Mediator kepada Pengurus mengenai selesainya Mediasi. Tugas-tugas lain yang diatur pada bagian lain dari Peraturan dan Prosedur ini, apabila ada. Terhadap permohonan Mediasi yang diterima sebagaimana dimaksud ayat (6), Sekretariat pada tanggal yang sama dengan tanggal konfirmasi dimaksud mencatatkan permohonan tersebut dalam 
buku register perkara LAPSPI. Pengurus dapat melimpahkan kewenangan melakukan konfirmasi atas pendaftaran Permohonan Mediasi kepada personil Sekretariat. ${ }^{17}$

\section{Konsep Keadilan dalam mediasi pada Lembaga Alternatif Penyelesaian Sengketa Perbankan Indonnesia (LAPSPI)}

Bank merupakan lembaga keuangan yang sangat dibutuhkan oleh masyarakat dalam melakukan transaksi keuangan, maupun transaksi lainnya. ${ }^{18}$ Mediasi Perbankan sangat diperlukan untuk membantu penyelesaian sengketa antara nasabah dengan bank secara murah, sederhana, cepat dan efissien, selain dapat menjaga kelangsungan hubungan antara nasabah dengan bank sehingga pada gilirannya mampu meningkatkan kredibilitas dan reputasi bank. ${ }^{19}$ Dalam dinamika perjalanan suatu kegiatan perbankan, tidak bisa dipungkiri bahwaa nasabah merupakan konsumen dari pelayanan jasa perbankan. Kedudukan nasabah dalam hubungannya dengan pelayanan jasa perbankan, berada pada dua posisi yang bergantian sesuai dengan sisi mana mereka berada. Pada dasarnya nasabah merupakan konsumen dari pelaku usaha yang menyediakan jasa di sektor usaha perbankan. ${ }^{20}$

Penyelesaian sengketa merupakan hal yang sangat biasa terjadi dalam kegiatan usaha atau bisnis, dimana dapat berujung pada suatu permasalahan/sengketa. Teori hukum yang berkaitan dengan pembahasan penyelesaian sengketa melalui Lembaga Alternatif Penyelesaian Sengketa Perbankan Indonesia (LAPSPI) salah satunnya adalah teori keadilan

Kemudian jika ditinjau dari aspek teoritis, bahwa teori strategi penyelesaian sengketa menggunakan lembaga yang hidup dan berkembang dalam masyarakat adalah dibolehkan. Hal itu dampak dari model penyelesaian sengketa yang ditawarkan oleh Dean G. Pruitt dan Jeffrey Z. Rubin yang mana mengemukakan ada lima strategi dalam penyelesaian sengketa, yaitu meliputi contending (bertanding), yielding (mengalah), problem solving (pemecahan masalah), with drawing (menarik diri). ${ }^{21}$

Dari kelima cara penyelesaian sengketa yang sesuia dengan nasabah dan pihak yang terkait yaitu menggunakan strategi penyelesaian sengketa dengan cara problem solving,

\footnotetext{
${ }^{17}$ Peraturan dan Prosedur mediasi 2017 oleh LAPSPI

${ }^{18}$ Adiwidjaja dan Rivai Wirasasmita, (2000), Analisis Kredit, Bandung: Pionir Jaya, hlm.11

19 Nahdhah, (2016 ), "Mediasi Sebagai Alternatif Penyelesaian Sengketa Perbankan", Badamai Law Journal, Vol. 1, Issues 1, April 2016 https://ppjp.ulm.Ac.id/journal/index.php/blj/article/view/254/196

${ }^{20}$ Muhamad Djumhana, (2003), Hukum Perbankan di Indonesia, Bandung: Citra, hlm.282

${ }^{21}$ Salim HS, (2014), Penerapan Teori Hukum pada Peneltian Tesis dan Disertasi, Jakarta : PT. Raja Grafindo Persada, Cet. Ketiga, hlm. 144
} 
dengan mencari pemecahan suatu masalah sehigga dapat terselesaikan masalah antar kedua belah pihak.

Dalam menyelesaikan sengketa pada Lembaga Alaternatif Penyelesaian Sengketa Perbankan Indonesia (LAPSPI) menurut John Rawls yang dikenal sebagai salah satu filsuf yang secara keras mengkritik sistem ekonomi pasar bebas khususnya keadilan pasar sebagaimana yang dianut oleh Adam Smith. Menurut John Rawls dengan "Prinsip Keadilan Disributif Rawls". Kebebasan merupakam hak asasi manusia. Rawls menetapkan kebebasan sebagai prinsip pertama dari keadilannya berupa "Prinsip kebebasan yang sama" prinsip ini berbunyi bahwa "setiap orang harus mempunyai hak yang sama atas sistem kebebasan serupa bagi semua". Ini berarti pada tempat pertama keadilan dituntut agar semua orang diakui, dihargai, dan dijamin haknya atas kebebasan secara sama ${ }^{22}$

Berdasarkan keadilan, keterbukaan diberikan kepada setiap orang dan yang menjadi haknya, memberi ciri khas kepada keadilan sebagai norma moral. Pertama, keadilan selalu tertuju kepada orang lain, kedua keadilan harus ditegakkan, ketiga keadilan selamanya menuntut kesetaraan. Permasalahan keadilan akan terus diupayakan untuk dicapai, sesuai dengan tujuan yang tercantum dalam sila kelima didalam pancasila, yaitu keadilan sosial bagi seluruh rakyat Indonesia. Untuk mewujudkan keadilandibutuhkan kekampuan bersikap etis.

Secara khusus saat kita berbicara mengenai aspek keadilan dari pengaturan mediasi perbankan. Analisis dapat dilakukan dengan membedah ketentuan-ketentuan dalam POJK No. 01/POJK.07/2014 tentang Lembaga Alternatif Penyelesaian Sengketa, pisau analisis yang digunakan adalah teori keadilan (Teori etis) yang bertujuan untuk meningkatkan efektifitas dan memperkuat nilai keadilan bagi pihak-pihak yang memilih menyelesaikan sengketanya melalui jalan mediasi perbankan.

Keadilan memerlukan pemahaman yang tepat terutama jika dikaitkan dengan berbagai kepentingan yang demikian komplek. Keadilan menurut Aristoteles, ${ }^{23}$ dalam karyanya "Nichomachean ethics", artinya berbuat kebajikan, atau dengan kata lain, keadilan adalah kebajikan yang utama. Menurut Aristoteles, "justice consists in treating equals equally and

${ }^{22}$ Munir Fuady, (2010), Dinamika Teori Hukum, Jakarta: Bogor Ghalia Indonesia, hlm. 34

${ }^{23}$ Robert Reiner dalam tulisannya berjudul "Justice" menggambarkan perdebatan tentang keadilan sebagai suatu "essentially contested concept," hal ini bermakna bahwa sebagai sebuah konsep, keadilan merupakan konsep abstrak dan interpretatif-visioner (ditentukan oleh pemahaman dan cara pandang masingmasing). Dalam James Penner et. Al. (editors), (2002), Introduction to Jurisprudence and Legal Theory (Commentary and Materials), London: Butterworths, hlm. 719. Menurut Plato, keadilan merupakan bagian dari virtue (kebajikan). Periksa Burhanuddin Salam, (1997), Etika Sosial, Jakarta: Rineka Cipta, hlm. 117. Dikutip dari Agus Yudha Hernoko, (2010), Keseimbangan Versus Keadilan Dalam Kontrak (Upaya Menata Struktur Hubungan Bisnis dalam Perspektif Kontrak yang Berkeadilan), Fakultas Hukum Universitas Airlangga, Surabaya. 
unequals unequally, in proportion to their inequality." Prinsip ini beranjak dari asumsi "untuk hal-hal yang sama diperlakukan secara sama, dan yang tidak sama juga diperlakukan tidak sama, secara proporsional."

Teori keadilan (Teori etis), dikaji dari sudut pandang falsafah hukum (Memberikan keadilan bagi masyarakat). Menurut teori etis, hukum semata-mata bertujuan untuk keadilan. Dengan perkataan lain, hukum menurut teori ini bertujuan merealisir atau mewujudkan keadilan. Hakikat keadilan adalah penilaian terhadap suatu perlakuan atau tindakan dengan mengkajinya dengan suatu norma yang menurut pandangan subjektif (subjektif untuk kepentingan kelompoknya, golongannya dan sebagainya) melebihi norma norma lain.

Dalam hal ini ada dua pihak yang terlibat, yaitu pihak memperlakukan dan pihak yang menerima perlakuan. Pada umumnya keadilan merupakan penilaian yang hanya dilihat dari pihak yang menerima perlakuan saja, jadi penilaian tentang keadilan ini pada umumnya hanya ditinjau dari satu pihak saja, yaitu pihak yang menerima perlakuan. Apakah pihak yang melakukan tindakan atau kebijaksanaannya tidak dapat menuntut tindakan atau kebijaksanaannya itu dinilai adil. Kalau kebijaksanaan pemerintah telah dipertimbangkan matang-matang bahwa hal itu demi kepentingan umum, tetapi ada warga negara yang tidak sepenuhnya terpenuhi kebutuhannya, apakah kebijaksanaan pemerintah itu dapat dinilai tidak adil. Keadilan kiranya tidak harus hanya dilihat dari satu pihak saja, tetapi harus dilihat dari dua pihak.

Aristoteles membedakan adanya dua macam keadilan, yaitu justitia distributiva (distributive justice, verdelende, atau begevende gerechtigheid) dan justtia commutative (remedial justice, vergeldende, atau ruilgerechtigheid).

Justitia distributive menuntut bahwa setiap orang mendapat apa yang menjadi hak atau jatahnya: suum cuique tribuere (to reach hos own). Jatah ini tidak sama untuk setiap orang, tergantung pada kekayaan, kelahiran, pendidikan, kemampuan, dan sebagainya; sifatnya profesional. Yang dinilai adil disini adalah apabila setiap seorang mendapatkan hak atau jatahnya secara proporsional. Justitia distributiva merupakan tugas pemerintah terhadap warganya, menentukan apa yang dapat dituntut oleh warga masyarakat. Justitia distributiva ini merupakan kewajiban pembentuk undang-undang untuk diperhatikan dalam menyusun undang-undang. Keadilan ini memberi kepada setiap orang menurut jasa atau kemampuannya. Disini bukan kesamaan yang dituntut, tetapi perimbangan. 
Justtia commutative memberi kepada setiap orang sama banyaknya. Dalam pergaulan didalam masyarakat, justtia commutativa merupakan kewajiban setiap orang terhadap sesamanya. Disini yang dituntut adalah kesamaan. Yang adil adalah apabila setiap orang diperlakukan sama tanpa memandang kedudukan dan sebagainya.

Kalau justtia commutativa itu sifatnya proporsional, justtia commutativa karena memperhatikan kesamaan, sifatnya mutlak. Didalam perjalanan sejarah, isi keadilan itu ditentukan secara historis dan selalu berubah menurut tempat dan waktu, maka tidak mudah menentukan isi keadilan. Kalau dikatakan bahwa hukum bertujuan mewujudkan keadilan, itu berarti bahwa hukum identik atau tumbuh dengan keadilan.

Dalam POJK No. 01/POJK.07/2014 Lembaga Alternatif Penyelesaian Sengketa Perbankan pada Pasal 7 menyebutkan prinsip keadilan pada Lembaga Alternatif Penyelesaian Sengketa memiliki peraturan dalam pengambilan putusan dengan ketentuan sebagai berikut:

a. Mediator benar-benar bertindak sebagai fasilitator dalam rangka mempertemukan para pihak yang bersengketa untuk memperoleh kesepakatan penyelesaian

b. Ajudikator dan arbiter dilarang mengambil putusan berdasarkan pada informasi yang tidak diketahui para pihak, dan

c. Ajudikator dan arbiter wajib memberikan alasan tertulis dalam setiap putusannya

Lembaga Alternatif Penyelesaian sengketa memberikan alasan tertulis atas penolakan permohonan penyelesaian sengketa dari konsumen dan atau lembaga jasa keuangan.

Pada pasal 7 huruf a menyebutkan "Mediator benar-benar bertindak sebagai fasilitator dalam rangka mempertemukan para pihak yang bersengketa untuk memperoleh kesepakatan penyelesaian" dalam hal ini dapat dijelasnkan bahwa pihak yang bersengketa yaitu antara bank dan nasabah diberlakukan secara sama yaitu pada penilaian terhadap suatu perlakuan/tindakan. Adanya kesetaraan antara bank dan nasabah yang diberlakukan oleh mediator yang bertindak sebagai fasilitator, ini berate keputusan mediasi merupakan keputusan yang diharapkan kedua belah pihak dan benar-benar mencapai tujuan win-win solution. Pihak bersengketa mendapatkan hak/jatahnya sebagaimana dan seharusnya mereka dapatkan (to reach hos own) secara proporsional menurut jasa/kemampuannya.

Besarnya jumlah permohonan sengketa yang masuk ke LAPSPI, menunjukkan bahwa keberadaan LAPSPI ini bukan hanya semakin dikenal oleh masyarakat, namun juga semakin 
dimanfaatkan. Jadi trust itu semakin meningkat baik oleh konsumen maupun oleh industri perbankan. Artinya, LAPSPI semakin menjadi pilihan alternatif untuk penyelesaian sengketa di luar pengadilan. Mediasi merupakan cara penyelesaian sengketa melalui mediator LAPS untuk membantu pihak yang bersengketa mencapai kesepakatan.

\section{PENUTUP}

Konsep keadilan yang dilakukan oleh Lembaga Alternatif Penyelesaian Sengketa Perbankan (LAPSPI) adalah sebagaimana POJK No. 01/POJK.07/2014 Lembaga Alternatif Penyelesaian Sengketa Perbankan pada Pasal 7 menyebutkan prinsip keadilan pada Lembaga Alternatif Penyelesaian Sengketa memiliki peraturan dalam pengambilan putusan dengan ketentuan sebagai berikut: Mediator benar-benar bertindak sebagai fasilitator dalam rangka mempertemukan para pihak yang bersengketa untuk memperoleh kesepakatan. Penyelesaian dalam hal ini dapat dijelaskan bahwa pihak yang bersengketa yaitu antara bank dan nasabah diberlakukan secara sama yaitu pada penilaian terhadap suatu perlakuan/tindakan

\section{Buku}

\section{DAFTAR PUSTAKA}

Adiwidjaja dan Rivai Wirasasmita, 2000, Analisis Kredit, Bandung, CV Pionir Jaya

Agus Yudha Hernoko, 2010, Keseimbangan Versus Keadilan Dalam Kontrak (Upaya Menata Struktur Hubungan Bisnis dalam Perspektif Kontrak yang Berkeadilan), Fakultas Hukum Universitas Airlangga Surabaya.

Burhanuddin Salam, 1997, Etika Sosial, Jakarta: Rineka Cipta.

Elisabeth Nurhaini Butarbutar, 2018, Metode Penelitian Hukum (Langkah-Langkah Untuk Menemukan Kebenaran Dalam Lmu Hukum), Bandung: PT Refika Aditama.

Gatot Soemartono, 2006, Arbitrase dan Mediasi di Indonesia, Jakarta: Gramedia

Felix Oentoeng Soebagjo, 2007, Mediasi Sebagai Alternatif Penyelesaian Sengketa Dibidang Perbankan, Bahan Diskusi Terbatas "Pelaksanaan Mediasi Perbankan oleh Bank Indonesia Dan Pembentukan Lembaga Independen Mediasi Perbankan”. Kerjasama Magister Hukum Bisnis Dan Kenegaraan, Universitas Gadjah Mada, Yogyakarta, Dan Bank Indonesia. Yogyakarta, 21 Maret 2007

Muhamad Djumhana, 2003. Hukum Perbankan di Indonesia, Bandung: Citra. 
Munir Fuady, 2010, Dinamika Teori Hukum, Jakarta: Bogor Ghalia Indoenesia.

Paulee A. Coughlin, 1994, The Movement of Consumer Protection in the European Community: A Vital Link in the Establishment of Free Trade and a Paradigm for North America, International and Competition Law Review, No. 143.

Rachmadi Usman, 2013, Pilihan Penyelesaian Sengketa di Luar Pengadilan, Bandung: PT. Citra Aditya Bakti

Robert Reiner dalam James Penner et. Al. (editors), 2002, Introduction to Jurisprudence and Legal Theory (Commentary and Materials), London: Butterworths

Salim HS, 2014, Penerapan Teori Hukum pada Peneltian Tesis dan Disertasi, Jakarta : PT. Raja Grafindo Persada

Sudaryatmo, 1999. Hukum dan Advokasi Konsumen. Bandung: PT. Citra Aditya Bakti

Susanti Adi Nugroho, 2008, Proses Penyelesaian Sengketa Konsumen Ditinjau dari Hukum Acara serta Kendala Implementasinya, Jakarta: Kencana

Syahrizal Abbas, 2009, Mediasi Dalam Perspektif Hukum Syariah, Hukum Adat, Dan Hukum Nasional, Jakarta: Kencana Perasada Media Group

\section{Jurnal}

Abdul Halim Barkatullah, "Urgensi Perlindungan Hak-hak Konsumen Dalam Transaksi Di ECommerce”, Jurnal Hukum No. 2 Vol. 14 April 2007: 247 - 270,

Andika Persada Putera, 2009, "Penyelesaian Sengketa Perbankan Dengan Mediasi”, Jurnal Yuridika No. 1 Vol 28 No 1

Inosentius Samsul, 2009, "Pengembangan Model Penyelesaian Sengketa Perbankan dalam Perpekstif Perlindungan Konsumen”, Buletin Hukum Perbankan dan Kebanksentralan, Direktur Hukum Bank Indonesia, Jakarta

Nahdhah, 2009, "Mediasi Sebagai Alternatif Penyelesaian Sengketa Perbankan”, Badamai Law Journal, Vol. 1, Issues 1, April 2016

Nahdhah , Ningrum Ambarsari, 2019, "Mediasi Perbankan melalui Lembaga Alternatif Penyelesaian Sengketa Perbankan Indonesia (LAPSPI)", Jurnal Banua Law Review Vol. 2. No. 1 https://balrev.ulm.ac.id/index.php/balrev/article/view/6/pdf 
Rika Delfa Yona, 2014, "Penyelesaian Sengketa Perbankan Syariah di Indonesia", Economic: Jurnal Ekonomi dan Hukum Islam, Vol. 4, No. 12014 ISSN: 2088-6365 https://d1wqtxts1xzle7.cloudfront.net/40894987/961-2934-2-PB.pdf

Yusuf Wahyu Wibowo, "Alternatif Penyelesaian Sengketa Perbankan Melalui Lembaga Alternatif Penyelesaian Perbankan Indonesia (Lapspi)", Universitas Lampung 2017. Http://digilib.unila.ac.id/25789/3/skripsi\%20tanpa\%20bab\%20pembahasan.pdf

OJK, Lembaga Alternatif Penyelesaian Sengketa LAPS, https://www.ojk.go.id/id/kanal/edukasi-dan-perlindungan-konsumen/Pages/LembagaAlternatif-Penyelesaian-Sengketa.aspx

\section{Peraturan perundang-undangan}

Peraturan Perundang-Undangan Undang-Undang Nomor 21 Tahun 2011 tentang Otoritas Jasa Keuangan (Lembaran Negara Tahun 2011 Nomor 111 dan Tambahan Lembaran Negara Republik Indonesia Nomor 5253).

Undang-Undang Nomor 30 Tahun 1999 tentang Arbitrase dan Alternatif Penyelesaian Sengketa (Lembaran Negara Republik Indonesia Tahun 1999 Nomor 138 dan Tambahan Lembaran Negara Republik Indonesia Nomor 3872).

Undang-Undang Nomor 10 Tahun 1998 tentang Perubahan Atas Undang- Undang Nomor 7 Tahun 1992 tentang Perbankan (Lembaran Negara Republik Indonesia Tahun 1998 Nomor 182 dan Tambahan Lembaran Negara Republik Indonesia Nomor 3790).

Peraturan Otoritas Jasa Keuangan Nomor 1/POJK.07/2014 tentang Lembaga Alternatif Penyelesaian Sengketa di Sektor Jasa Keuangan (Lembaran Negara Republik Indonesia Tahun 2014 Nomor 12 dan Tambahan Lembaran Negara Republik Indonesia Nomor 5499).

Peraturan Otoritas Jasa Keuangan Nomor 1/POJK.07/2013 tentang Perlindungan Konsumen Sektor Jasa Keuangan (Lembaran Negara Republik Indonesia Tahun 2013 Nomor 118 dan Tambahan Lembaran Negara Republik Indonesia Nomor ).

Peraturan Lembaga Alternatif Penyelesaian Sengketa Perbankan Indonesia Nomor: 07/LAPSPI-PER/2015 tentang Peraturan dan Prosedur Mediasi Surat Edaran Bank Indonesia Nomor: 8/14/DPNP/2006 Tentang Mediasi Perbankan.

Surat Edaran Otoritas Jasa Keuangan Nomor: 2/SOJK.07/2014 Tentang Pelayanan dan Penyelesaian Pengaduan Konsumen pada Pelaku Jasa Keuangan. 
Undang-Undang Republik IndonesiaNomor 7 Tahun 1992 sebagaimana telah diubah dengan Undang-Undang Nomor 10 Tahun 1998 Tentang Perubahan Undang-Undang Nomor 7 Tahun 1992 Tentang Perbankan. Lembaran Negara Republik Indonesia Tahun 1998 Nomor 182. Tambahan Lembaran Negara Republik Indonesia Nomor 3790.Selanjutnya disebut UU Perbankan.

Peraturan dan Prosedur mediasi 2017 oleh LAPSPI 